\title{
THE CUSTOMER SERVICE PROCESS: THE LEAN THINKING PERSPECTIVE
}

IE Working Paper

Daisy Escobar

Instituto de Empresa

Operations and Tech. Management Dep.

María de Molina 12, $5^{\mathrm{a}}$ planta

28006 Madrid, Spain

daisy.escobar@ie.edu
DO8-126-I

$11-03-2005$

\begin{abstract}
Lean thinking has proved to be successf ul in improving results in industry. Services could benefit from this approach too. The success of lea $n$ thinking depends on the appropriate identification and elim ination of waste. This paper describes the work carried out in identifying an d analysing waste in the custom er service process of a $\mathrm{m}$ ajor telecommunications operator. An Acti on Research approach was adopted, and a "lean team" of company personnel was specially formed to undertake the necessary fieldwork. The study insp ired management changes aimed at improving the customer service centre's performance.
\end{abstract}

\section{Keywords}

Service operations, lean thinking, organizational learning

\section{Acknowledgments}

We would like to thank the nine members of the lean team who took part in this investigation for their dedica tion, interest and enthusiasm . Without such invaluable participation, and a bove all, without their knowledge, this paper would not have been possible. 



\section{INTRODUCTION}

There are ever fewer doubts about the rising im portance of services in the more advanced economies (Fitzimmons and Fitzim mons, 2000; Roth and Menor, 2003). Nor is there any disagreement that, in spite of their im portance, services are misunderstood, mismanaged and misgauged (Henkoff, 1994; Bowen and Hallo well, 2002; Grönroos and Ojasalo, 2004). As well as this appraisal, which is born out by both academics and practitioners, there is the customers' view, whose satisfaction regardi ng services reveals som e shocking statistics (Bowen and Hallowell, 2002). "In sum , we don't seem to get the service "right" in either management practice or theory" (Bowen and Hallowell, 2002). This sentence is a blunt yet faithful evaluation of the current state of serv ices. The greatest irony is that we have been studying this for more than 30 years, since Prof. Theodore Levitt, in his now classic article "Production-line approach to service", proposed the "industrialisation" of services as the simple method of improving services' performance indicators (Levitt, 1972).

It is hardly surprising, then, that voices are be ing raised everywhere about the urgent need for research and work on im proving service management (Roth and Menor, 2003; Johnston, 1998; Gronröos and Ojasalo, 2004). Re search agendas have been opened to suit all interests and tastes. We, as teachers of operations management, have decided to "go back to our roots" (Johnston, 1998), to the analysis of processes, of their effectiveness and efficiency, but with the focus on services.

And how do we define services? While there is a whole host of definitions of services, the definition on which they are all converging is very close to the area of operations: services are basically processes which are characterised by the interaction between the custom er and the resources of the service provider ( $\mathrm{Gr}$ önroos, 1998; Sam pson, 1999; Fitzim mons and Fitzimmons, 2000; Grönroos, 2004). Services are processes, that is to say, we will have input, transformation activities and output.

In almost all today's companies, regardless of the "traditional" sector they belong to, there is a service process of relevant im portance because of its considerable im pact on customer perception and on the innovation and im provement of operations: it is the custom er service process. Within this customer service process, a particularly interesting sub-process can be identified: the service recovery process. We focus on this latter process.

The service recovery process, understood as action aimed at finding solutions to the failure of a service delivery system, is a topic of growing res earch interest. On the one hand is its im pact on customer loyalty and the subsequent effect on companies' income and profitability; and on the other, the valuable inform ation it provides on the cause $\mathrm{s}$ of the problem $\mathrm{s}$ which are at the root of complaints, making it a solid source of inform ation for continuous improvement (Tax and Brown, 1998; Johnston and Mehra, 2002). Studies show that, in spite of these benefits, the $m$ ajority of customers are not satisfied with the way in which organisations settle their com plaints, and a great many companies do not make the most of the learning opportunities provided by system failures

The purpose of this research paper, therefor $\mathrm{e}$, is to contribute to the understanding of service process management from an operational perspective, and more specifically, focusing 
through the lens of lean thinking, a philosophy wh ich is exporting the effective and efficient results obtained in industry to the service sector (Bowen and Youngdahl, 1998). By studying the operational practices at the Custom er Service Centre of a $\mathrm{m}$ ajor telecommunications operator, our aim is to answer the following que stion: Why does customer service not flow as the customer would like and in an effective wa y for the company? Customer service centres provide the first, and in $\mathrm{m}$ any cases, only access to the service recovery process in a good many organisations, be they service com panies or not. The significance of this case in particular is born out by the Spanish Confeder ation of Consumers and Users (CECU), which reports that in 2002, of all complaints received, 6.2 per cent came from users dissatisfied with telecommunications services, outstanding am ong the principle com plaints being custom er service, which "in 90 per cent of cases solves absolutely nothing, so that there are users who call more than 40 tim es and speak to different people who do not follow up their com plaint" (Consumer.es, 2003).

Given the complexity of such a process, we argue that it is im portant to study it as an integrative matter. Hence, action research was employed.

The outline of the paper is as follows: first, we establish a theoretical overview concerning service performance and lean thinking. W e then go on to explain our research design and execution. Subsequently, our em pirical findings are presented, followed by an analysis of waste identified in the customer service process. We end the paper with directions f or future research. 


\section{THEORETICAL BACKGROUND}

The effective and efficient $m$ anagement of se rvice processes is the challenge we have before us. We take effectiveness to $\mathrm{m}$ ean the extent to which a process adapts to custom er requirements, resulting in their satisfaction. Efficiency, $m$ eanwhile, is how the process converts resources to produce the output custom ers expect; in other words, how the resources used in becoming effective are consum ed. However, service processes are characterised by the fact that the custom er provides signifi cant input to the production process (Sam pson, 1999; Grönroos y Ojasalo, 2004). That input can be of three general types: the custom er $\mathrm{him} /$ herself, goods from the customer and/or information from the customer (Sampson, 1999). But customers do not only provide input (they themselves, information, requests, complaints), they also take part in the service process, influencing both the process's performance, that is to say its efficiency, and the perception of qua lity of the service produced, or rather its effectiveness (Grönroos and Ojasalo, 2004). In service processes, custom ers are more than mere consumers of output, they are co-producers of the process. Both concepts, effectiveness and efficiency, are therefore inseparable and this is how they are understood in the concept of service productivity (Grönroos y Ojasalo, 2004).

As far as models for the effective and effici ent management of services are concerned, our first point of reference is Prof. T. Levitt's proposal for the industrialisation of services (Levitt, 1972). He maintained that the quality - effectiveness - of services would improve quite clearly if they were approached with the sam e "industrial" mentality, or rather "changing people and coincidence for technology and system s". This logic of "industrialising" certainly rem ains valid, only now it should be achieved not by appl ying the industrial practices of the tim e, which correspond to mass production models, production based on trade-offs, but rather more modern practices, those of lean operations, wh ich enable efficient mass production practices to combine with flexible approaches from traditional artisan production, thus giving rise to the lean service (Bowen and Younhdal, 1995).

The magnificent performance advantages th at a lean producer has over typical $\mathrm{m}$ ass producers have been widely described (W omack, Jones and Roos, 1990). The principle of lean thinking m eans "moving towards the elim ination of all waste in order to develop an operation that is faster, $m$ ore dependable, produces higher quality products and services and, above all, operates at low cost" (Slack et al, 2004). Its prim ary goal is, therefore, to increase the efficiency of production by $m$ eans of the complete elimination of waste (Ohno, 1998), understanding as waste all that - time, cost, work - which does not add value from the point of view of the customer.

This waste can be defined, specifically for services, in the following way (George, 2003): a) Overproduction: production of services above and beyond what is necessary for immediate use; performing a service which the customer only requires at a later stage, or providing them with a service they have not requested. This waste is linked to the company's desire to achieve 100 per cent use of its resources. So, for exam ple, a telecommunications operator may choose to bring forward the date for transferring a line to a custom er simply because it proves $m$ ore convenient, because it has staff to keep busy or because with this request it can put together an "economic batch" of services. b) Waiting time: any delay between one activity and 
another. It is waste which cannot be recovere d. It may arise from staff difficulties in knowing what has to be done because of lack of training, lack of regularisation or lack of inform ation. And all this applies equally to the custom er since they are co-producers of the service. c) Defective products: any aspect of the service whic $h$ does not $m$ eet the custom er's requirements. It can range from losing inform ation to failing to $\mathrm{m}$ eet agreed deadlines, causing the customer to be dissatisfied. Som e defects are caused by incorrect inform ation, or by incorrect instructions, to nam e just two cause s. Someone in the flow realises there is a defect and has to reprocess the request, or go back on themselves. The waste associated with defective products is the cost of the extra $\mathrm{m}$ aterial (minimal or non-existent in the case of processes where the input is information) which cannot be recovered at the end of the process, as well as the costs of production work for the service (the tim e spent responding to the request in vain). d) Inventory: any work on processes in exce ss of what is required to be produced for the custom er; this could be calls on hold, requests for papers pending, e-m ails awaiting a reply, people in a queue. e) Motion: referring to the needless $m$ ovement of employees (to find information, for example). This waste is rare in services. f) Process: trying to add more value to a service/product than what the customer wants to pay for it; that is to say, doing more work than is absolutely necessary to satisfy customers, for example, multiple steps in order to approve som ething, or multiple calls in order to get an answer. g) Transport: referring to the unnecessary $m$ ovement of work (in a call centre, the $\mathrm{m}$ ovement of information, for example). This waste appears as customer requests being needlessly passed from one member of staff to another, from one department to another because no-one knows what to do with the request or no-one is " $i \quad n$ charge" of the process, or because staff performance indicators work against it being addressed.

The identification of this waste is the first step towards its elimination, which can notably improve productive efficiency. It is this identif ication of waste which generates a system atic problem solving process, the "repeating why five times", in order to uncover the root cause of the waste and elim inate it. Many researchers have come to the conclusion that solving problems creates knowledge. By knowledge creation through problem solving, a organization refines the understanding of its process and improve its business performance 


\section{RESEARCH DESIGN AND EXECUTION}

It is in this context of lean thinking principles that this paper tackles the analysis of a special type of service process, the service $r$ ecovery process. In order to do this, we identify and analyse the waste which prevents a service from flowing through the customer service process in an effective way for the customer and an efficient way for the company. This must activate a search for the causes of this waste or these obstacles so as to proceed to their com plete elimination.

In order to carry out this study, we chos e the custom er service centre of a $\mathrm{m}$ ajor telecommunications operator which currently has the implementation of the lean approach to their department, thus following the lead of the same operator's Facilities and Maintenance division, where lean manufacturing concepts are being applied to notable effect.

\section{Research design}

Since there are common goals between the investigators and the company, and a review of available literature reveals an absence of studies in this sense for service processes where the input for transformation is customer information, customer requests and/or complaints, we as researchers were also engaged in playing two additional roles: as teachers and consultants. On the one hand, we had to introduce academ ic knowledge and theory on lean thinking and, on the other, we had to provide feedback throughout the study. This placed us in a very specific variant of the case study method known as action research.

Action research is a relevant, valid and necessary methodology for tackling the problem $\mathrm{s}$ faced by operations managers in today's companies. We have "to engage with real operations managers and focus our efforts on helping them deal with the actual problems they are facing in today's complex and fast-changing world" (Hayes, 2000).

Action research is applicable to issues which are not structured or integral and which are broadly relevant to practitioners. It is related to issues which cannot be shaped but which must be managed (Westbrook, 1995). Specifically, in the customer service process under study, the problem to be tackled was fuzzy and unstructure d, required an integral, system atic approach and more importantly, its administration poses a real challenge to its managers.

\section{Research execution}

Using the described approach, the research was carried out in the following steps: 1) Basic agreements on the developm ent of the joint pr oject; 2) diagnosis; 3) setup of knowledge; 4) action; 5) feedback; 6) action; 7) feedback.

\section{Step 1 - Agreements}

The first step was to meet the customer service centre management, consisting of the head and deputy heads, in order to: a) understand the situation and define the problem , thus restricting the study to a specific service which would act as a pilot for fam iliarisation with lean thinking principles and $\mathrm{m}$ ethodology, a le ss complex service com pared to the other services in this division, and over which the cu stomer service centre had greater control; $b$ ) agree on the aim s and scope of the study, which fo rtunately coincided with the goals of this 
research as expressed in the Research aim section; c) clarify the methodology, an explanation of what it consisted of was o ffered and received an enthusiastic response; d) select the participating team, agreeing that it should be form ed by members of all the departm ents which take part in the chosen service, fi nally consisting of nine people, including the division's manager; e) draw up a schedule.

\section{Step 2 - Diagnosis}

Using an interview format, the aim of this step was to review the type of information the company already had on queries, their classification, volum es, times and custom er satisfaction. As far as custom er satisfaction is concerned, the studies $m$ ade by the custom er service centre reveal that customers complain about the process's capacity to solve problems, both in terms of speed (it takes a long time) and in the reliability of the information given. So, we classified the complaints in two types. Once again, at this stage, only the three $\mathrm{m}$ embers of the management team took part.

\section{Step 3 - Setup of knowledge}

The purpose of this stage was to instruct all the members of the "lean team", as it came to be known, in the basic concepts of lean thinki ng (process, flow, service $\mathrm{m}$ aps, value, waste, cycles). To do so, a seminar was held with the following content: 1) discussion of a mini-case of poor service in a different context from telecommunications so as to highlight the concepts of effectiveness and efficiency, as well as the c oncept of service seen as a process; 2) next, they were introduced to the concepts of lean manufacturing via a simulation carried out using Lego pieces, since these people had no previous experience of this approach, accom panying this action learning with a reading on waste in industry, its nature and program mes to eliminate it; 3 ) then the case of a customer's complaint to a telecommunications company was discussed, a case which was the copy of a letter th is customer sent to another departm ent of the company in question and which we obtained directly from the customer; the purpose of this exercise was to analyse the waste present in this process from the point of view of the customer; 4) finally, there was a presentati on followed by a discussion on the concepts and principles of lean manufacturing and its application to lean service.

\section{Step 4 - Action}

All members of the lean team and we ourselv es simultaneously monitored the customer's request to the chosen service together, with the aim of drawing up a process $m$ ap of the service (a value stream) and identifying and analys ing the existing waste. In this exercise we used the following questions: What adds value from the customer's point of view? What kind of waste do we see in the process? How can service be done without the consum er waiting and without interruption? With this step, we made sure that all members of the lean team had understood the essential elements of process analysis from the lean perspective.

\section{$<$ Insert table 1 about here $>$}

\section{Step 5 - Feedback}

Based on the work done at the previous stage, we conducted a more detailed analysis and presented it to the group where the questions we re raised on possible causes of waste and the ways of eliminating it. The list of possible causes arose at this point: C1) incom plete 
information, C2) information unavailable in real time, C3) fragmented information, disjointed information, separated knowledge (each em ployee and/or departm ent has a scrap of information), C4) ignorance on the part of the employees involved at all points of the process, C5) lack of will on the part of em ployees, lack of motivation, C6) inappropriate tools for diagnosis and monitoring, C7) very open processes, C8) the different language used (between departments and between these and the custom er), C9) conflicting performance indicators ("I shouldn't take too long with this custom er because it goes against m y work results"), C10) policy and/or procedure which is not focuse $\mathrm{d}$ on the custom er, C11) no-one takes on the problem as their own; C12) others.

\section{Steps 6 and 7 - Action and Feedback}

Using the methodology learned in step 4, the $m$ embers of the lean team, who were divided into four groups, analysed a further $31 \mathrm{com}$ plaints. To do so, they used a form at which gathered together the monitoring of each complaints, as can be seen in Table 1. An initial draft of this table was presented as of step 4 and, with the lean team's contributions, the final version appears below. Finally, the results and analysis were presented to all members of the "lean team". 


\section{RESEARCH FINDINGS}

Apart from the identification and understanding of the waste in the service process under study, the research also provided a thorough insi ght into the way in which the custom er service process evolves. The research especially helped all the participants to $f$ orm a single, global perception from the customer's point of view. In addition, the results obtained include the learning process experienced over the course of the investigation.

\section{Steps 1, 2 and 3 - Agreements, Diagnosis and Setup of knowledge}

All the agreem ents were possible because bot $h$ parties were convinced of the $m$ utual benefits. They learned to apply a concept wh ich they felt was necessary and we gathered knowledge of the learning process. This proved essential to registering pertinent, relevant and sufficient information, as was, and m ost importantly, the desire of those taking part to do a professional job.

While the company has abundant information about customer requests since calls are registered minute-by-minute on a data base, it is information stored in silos. There is no integral approach from the customer's point of view.

Outstanding at this stage was the open-m indedness of all those taking part and their generosity with individual knowledge placed at the service of a common project. The teaching experience was never so rewarding.

\section{Steps 4, 5, 6 and 7 - Action, feedback, action and feedback}

The most striking point at these stages was the difficulty experienced in transferring waste to the customer service process context.

It was interesting listening to the participants as they discovered how the customer is a coproducer of the service. In many cases, incorrect information supplied by the customer had an impact both on the quality of the service and the com pany's performance. This observation serves to confirm that in service processes effi ciency and effectiveness are intrinsically linked, owing to a large degree to the customer's participation in the process (Grönroos and Ojasalo, 2004).

As result of our analysis of the sam ple of complaints, we observe custom ers make an average of eight calls to the system, which is no guarantee that their queries are answered since there is no alarm or checking system to indicate that the process has ended to the customer's satisfaction. In fact, the lean team realised itself that it is effectively the custom er who provides notice of the progress of their request at the different stages, an authentic "pull" system, but one which is corrupted. On average, the system only calls the custom er twice, a very "lean" use of resources, but hardly effec tive with a view to the custom er's perception. The system acknowledges that after the third call, it is faced with a problem of quality in the process. In addition, the customer speaks on average to nine different people, having to repeat the cause of their query and its progress each time: a waste both for the custom er and the system. 
As far as the waste discovered is concer ned, waiting tim e $(35 \%)$ figures as the $m$ ost important, followed by defective products $(22 \%)$ and unnecessary processes $(17 \%)$ and excess of transport (17\%).

The most significant causes of the main waste are incomplete information, and information unavailable in real time, and fragmented information (28\%); the lack of will and m otivation on the part of em ployees (19\%) and procedures which are not focused on custom ers and/or which are very loose $(24 \%)$. W hit respect to this, it is worth highlighting two im portant observations made by the "lean team " in the process of identifying waste. Firstly, the confirmation of the role which the custom er plays in the efficiency and effectiveness of the process, more so when it was they them selves, with less knowledge of the com pany's processes than any em ployee, who tugged at th e service chain $m$ anagement so that their request might "flow" through the system.

The second observation is related to a goal of the custom er service centre's management in the medium-term: the organisation which learns . When the three $m$ ost important causes of waste arose, those related to incorrect/unavaila ble information, those owing to the lack of motivation/will on the part of employees and those caused by procedures which do not f ocus on the customer, the "lean team ", emulating the Toyota style, began to repeatedly ask why. And one of their initial conclusions was that the lack of motivation/will on the part of employees could be a result of the frustration th ey feel at not having the right inform ation at the right time and/or at having too m any procedures which respond to an internal view rather than that of the customer.

\section{$<$ Insert table 2 about here $>$}

The analysis of the waste $m$ ost associated with each type of com plaint (type 1: the salesperson does not return the custom er's call, $67 \%$, and type 2 : The salesperson returns the call but does not solve the problem, 33\%) reveals differences rega rding waste. Table 2 shows that the tim $\mathrm{e}$ the customer is on hold ( D2) without their request bei ng processed is by far the most significant of the complaints where the custom er's call is not retu rned. This type of waste causes an unnecessary lengthening of the service recovery process. However, in those calls where the reason for discontent was the failure to solve a problem , as well as the waiting tim e (D2), the waste related to the production of defective products (D3) and the ex cess of transport (D7) take on particular importance. In these last cases the com plaint is incorrectly diagnosed and not solved appropriately, which requires a fresh diagnosis and solution. Th e unnecessary repetition of diagnosis and solution bounces the problem around the organisation according to its diagnosis, lengthening the service recovery process.

\section{$<$ Insert table 3 about here $>$}

As waste changes, so do the causes which generate it (Table 3). Therefore, the complaints where the call is not returned, in additi on to the initial waste, the waiting tim e, are primarily related to two types of cause: lack of motivation on the part of the employee and policies and procedure which are not focused on the custom er. On the other hand, th e complaints caused by dissatisfaction with the response provided by the com pany essentially have their root in irregularities in the inform ation 
being handled, such as, for exam ple, incomplete information, fragmented information or information which is not integral and differences of language between departments.

Analysing the im pact of waste on two variable $\mathrm{s}$ of com pany results, the level of custom er satisfaction, or effectiveness, and com pany efficiency, we found that waste is seen to have a significant effect on a company's results. On a scale of 1 to 5, we got that the average assessment of the impact on results of the different types of waste stands above 4 . Table 4 shows the assessment of the impact of the different waste under consideration against the amount of waste of that type which has been produced. It is plain to see that give $n$ the greater proportion with which waste of waiting time appears, this is the one which does $\mathrm{m}$ ost harm to the com pany, mainly because of the dissatisfaction it generates among customers. Second is the impact of the waste relating to receiving defective products. Finally, we find that waste related to transport and processes im pact on company's levels of efficiency more than on customer satisfaction.

$<$ Insert table 4 about here $>$ 


\section{CONCLUSIONS}

The immediate outcome of the study is the $d$ ecision on the part of the custom er service centre management under study to press ahead $\mathrm{w}$ ith the eradication of the $\mathrm{m}$ ost significant waste: that related to inf ormation and pro cedures and policies which do not focus on the customer and which are too loose. In addition, the "lean team" is now m otivated to devise procedures which prevent a customer from having to call the system more than three times, or which sound the alarm that something has gone wrong with the customer's request. They are already considering Poka-Yokes, a well-known concept in lean manufacturing.

Our research rem ains in progress. The next steps will be to guide the team in the elimination of the waste and in the knowle dge creation that will im prove the business performance.

There are other service processes which seem to be potential candidates to benefit from the implementation of lean thinking. To begin wit $h$, companies from various sectors have $m$ ajor customer service centres where the input is simply customer information. It would be interesting to compare this same process in companies from different sectors.

We hope that with this research we are contributing to the developm ent and advancement of service management. 


\section{Tables and graphics}

Table 1 - Life of a customer request

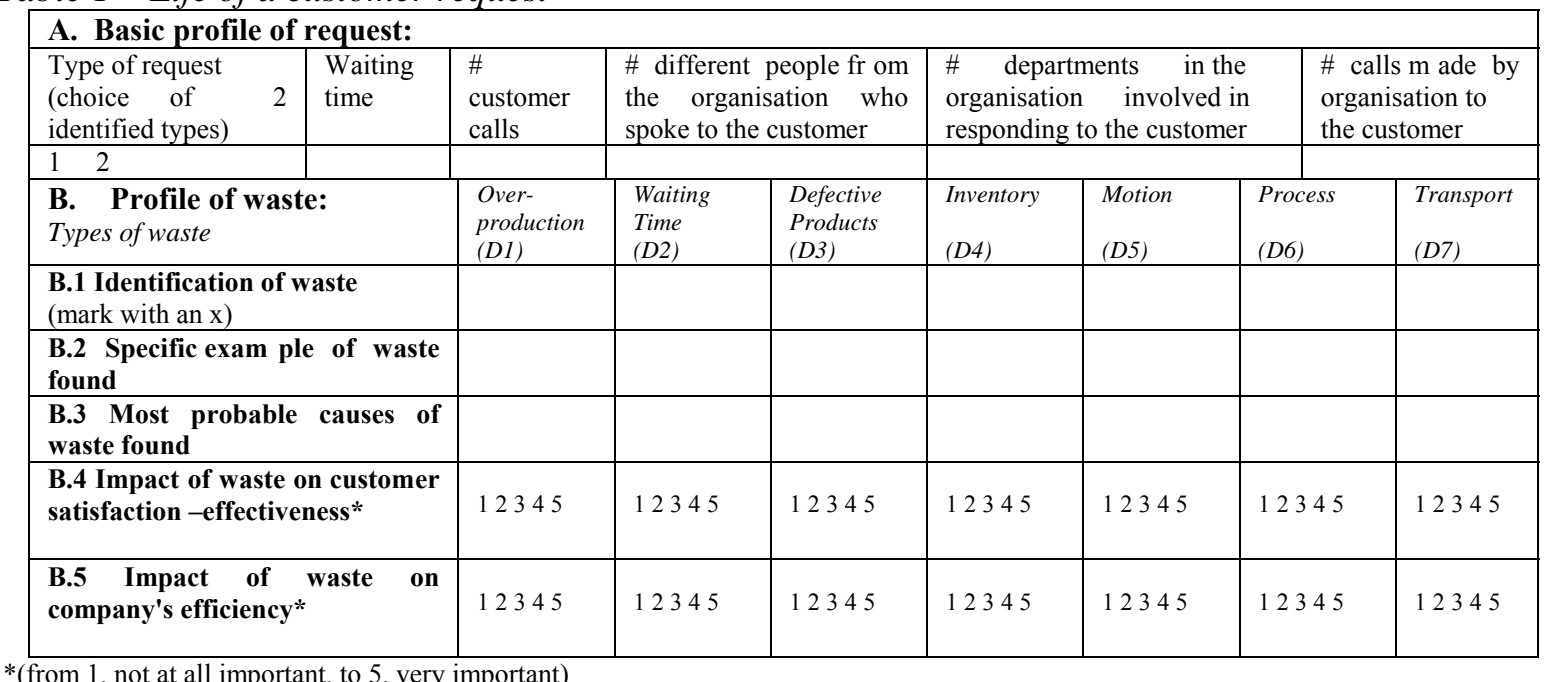

\begin{tabular}{|l|l|l|l|l|l|l|l|}
\hline Waste & $\begin{array}{l}\text { Over- } \\
\text { production } \\
(\mathrm{D} 1)\end{array}$ & $\begin{array}{l}\text { Waiting } \\
\text { Time } \\
(\mathrm{D} 2)\end{array}$ & $\begin{array}{l}\text { Defective } \\
\text { Products } \\
(\mathrm{D})\end{array}$ & $\begin{array}{l}\text { Inventory } \\
(\mathrm{D} 4)\end{array}$ & $\begin{array}{l}\text { Motion } \\
(\mathrm{D} 5)\end{array}$ & $\begin{array}{l}\text { Process } \\
(\mathrm{D})\end{array}$ & $\begin{array}{l}\text { Transport } \\
(\mathrm{D})\end{array}$ \\
\hline Type 1 & $0 \%$ & $36 \%$ & $16 \% 14 \% 2$ & $2 \%$ & & $18 \%$ & $14 \%$ \\
\hline Type 2 & $3 \%$ & $29 \%$ & $29 \% 0 \%$ & & $0 \%$ & $16 \%$ & $23 \%$ \\
\hline
\end{tabular}

Table 2 - Type of waste according to type of complaint

\begin{tabular}{|l|l|l|l|l|l|l|l|l|l|l|l|l|}
\hline Causes & $C 1$ & $C 2$ & $C 3$ & $C 4$ & $C 5$ & $C 6$ & $C 7$ & $C 8$ & $C 9$ & $C 10$ & $C 11$ & $C 12$ \\
\hline Type 1 & $8 \%$ & $5 \%$ & $12 \%$ & $3 \%$ & $29 \%$ & $4 \%$ & $7 \% 6 \%$ & & $1 \%$ & $15 \%$ & $6 \%$ & $6 \%$ \\
\hline Type 2 & $20 \%$ & $4 \%$ & $12 \%$ & $7 \%$ & $9 \%$ & $10 \%$ & $10 \% 12 \% 1 \%$ & & $14 \%$ & $0 \%$ & $0 \%$ \\
\hline
\end{tabular}

Table 3 - Types of causes according to type of complaint

\begin{tabular}{|l|l|l|l|l|l|l|l|}
\hline & $\begin{array}{l}\text { Over- } \\
\text { production } \\
(D 1)\end{array}$ & $\begin{array}{l}\text { Waiting } \\
\text { Time } \\
(D 2)\end{array}$ & $\begin{array}{l}\text { Defective } \\
\text { Products } \\
(D 3)\end{array}$ & $\begin{array}{l}\text { Inventory } \\
(D 4)\end{array}$ & $\begin{array}{l}\text { Motion } \\
(D 5)\end{array}$ & $\begin{array}{l}\text { Process } \\
(D 6)\end{array}$ & $\begin{array}{l}\text { Transport } \\
(D 7)\end{array}$ \\
\hline Customer satisfaction & 5 & 125 & 60 & 220 & & 25 & 19 \\
\hline Efficiency & 5 & 98 & 62200 & & & 44 & 25 \\
\hline
\end{tabular}

Table 4 - Importance of waste in the effectiveness and efficiency of the company 


\section{REFERENCES}

Bowen, D.E. and Hallowell, R. (2002), "Suppose we took service seriously? An introduction to the special issue," Academy of Management Executive, Vol.16, No.4, pp. 69-72

Bowen, D.E., Youngdahl, W .E. (1998), "Lean Se rvice: in defense of a production-line approach,” International Journal of Service Industry Management, Vol.9, No.3, pp. 207-225.

Fitzsimmons, J.A. and Fitzsim mons, M.J. (2000), Service Management, Operations, Strategy, and Information Technology, Irwin/McGraw-Hill, New York.

George, M.L. (2003), Lean Six Sigma for Service, The McGraw-Hill Companies, New York.

Grönroos, C. (1998), Service Marketing Theory: Back to Basics (working paper), Swedish School of Economics and Business Administration, Helsinki.

Grönroos, C. and Ojasalo, K.(2004), "Service productivity: Towards a conceptualization of the transform ation of inputs in to economic results in services," Journal of Business Research,Vol.57,pp.414-423.

Hayes, R.H. (2000), "Towards a 'New Architecture” for POM, Production and Operations Management, Vol.9, No.2, pp. 105-110.

Henkoff, R. (1994), "Service Is Everybody's Business," Fortune, 27 June 1994, pp. 48-60.

Johnston, R. (1998), "Service operations management: return to roots," International Journal \& Production Management, Vol.19, No.2, 1999, pp. 104-124.

Johnston, R. and Mehra, S. (2002), "Best-practice com plaint management," Academy of Management Executive, Vol.16, No.4, pp.

Levitt, T. (1972), "Production-line approach to service," Harvard Business Review, Vol.50, No.5, pp. 20-31.

Ohno, T. (1988), Toyota Production System, Beyond Large-Scale Production, Productivity, New York.

Roth, A.V. and Menor, L.J. (2003), "Insights into service operations m anagement: a research agenda," Production and Operations Management Vol.12, No.2, pp.145-164.

Sampson, S.E. (1999), Understanding service businesses, Brigham Young University.

Slack, N., Chambers, S. and Johnston, R. (2004), Operations Management, Prentice HallFinancial Times.

Swank, C.K. (2003), “The Lean Service Machine,” Harvard Business Review, Vol.81, No.10, pp.123-129.

Tax, S.S. and Brown, S.W . (1998), "Recoveri ng and Learning from Service Failure," Sloan Management Review, Vol.40, No.1, pp. 75-88.

Westbrook, R. (1995), “Action research: a new paradigm for research in production and operations management," International Journal of Operations \& Production Management, Vol.15, No.12, pp. 6-20.

Womack, J.P., Jones, D.T. and Roos, D. (1990), The Machine that Changed the World: The Story of Lean Production, Harper Collins, New York. 
NOTAS 